\title{
Introduction: balancing the scales: assessing the efficacy of global court mediation reform
}

\section{OVERVIEW}

Since the mid-twentieth century, the question of achieving procedural and substantive justice in the context of judicial mediation has received significant attention beginning with the work of Owen Fiss and Lon Fuller. Recent work has highlighted the growing inefficiencies of civil litigation in economically advanced countries, while at the same time, cautioning judiciaries to ensure that justice is safeguarded in extra-judicial procedures. ${ }^{1}$ Building on a growing body of empirical cross-jurisdictional research examining mediation reform and policy, ${ }^{2}$ this book explores

1 See M. Galanter, "Why the "Haves" Come Out Ahead: Speculations on the Limits of Legal Change' (1974) 9(1) Law and Society Review 95; M. Feeley, The Process is the Punishment: Handling Cases in a Lower Criminal Court (New York: Russell Sage Foundation, 1979); C. Albiston, 'The Rule of Law and the Litigation Process: The Paradox of Losing by Winning' (1999) 33(4) Law and Society Review 869; H. Genn, Judging Civil Justice (Cambridge University Press, 2010); A.J. Cohen, 'Revisiting Against Settlement: Some Reflections on Dispute Resolution and Public Values' (2009) 78 Fordham Law Review 101.

2 See F. Steffek et al., Regulating Dispute Resolution: ADR and Access to Justice at the Crossroads (Oxford: Hart, 2013); Schonewille \& Schonewille, Variegated Use of Mediation: A Comparative Study of Mediation Regulation and Practices in Europe and the World (The Hague: Eleven International Publishing, 2014); D. Stienstra, T.E. Willging and Federal Judicial Center, Alternatives to Litigation: Do They Have a Place in the Federal District Courts? (Washington, DC: Federal Judicial Center, 1995); R.L. Wissler, 'Mediation and Adjudication in the Small Claims Court: The Effects of Process and Case Characteristics' (1995) 29 Law and Society Review 323; C. Menkel-Meadow, 'Regulation of Dispute Resolution in the United States of America: From the Formal to the Informal to the "Semi-formal"" in F. Steffek et al. (eds), Regulating Dispute Resolution: ADR and Access to Justice at the Crossroads (Oxford: Hart, 2013); T. Stipanowich, 'The International Evolution of Mediation: A Call for Dialogue and Deliberation' (2015) 46 Victoria University of Wellington Law Review 1191; S.I. Strong, 'Realizing Rationality: An Empirical Assessment of International Commercial Mediation' (2016) Washington 
initial comparative findings examining the association between judicial voluntary and mandatory mediation structure and perceptions of justice, efficiency and confidence in courts. It suggests that variation among such programmes reflects distinct approaches to individual and collective responsibility for the financial, social and temporal resources required for resolution. As many such civil mediation programme reforms have been underway for more than a decade, it is timely to examine lessons learned in the implementation of such programmes. In doing so, the book highlights positive lessons learned from selected jurisdictions, analyses local circumstances, and distils best practices.

In numerous jurisdictions worldwide, civil justice reform has advanced rapidly in recent years since the early days of the 'multi-door courthouse'. ${ }^{3}$ In response to what has been described as 'a sharp increase in the number, rapidity and complexity of transactions' ${ }^{3}$ characterized by 'cumbersomeness, costliness and legal unpredictability', ${ }^{5}$ reform proposals have been advanced, including the introduction of mediation in civil case administration. ${ }^{6}$ Existing scholarship has examined the varying intrinsic and extrinsic rationales motivating courts to introduce mediation programmes, ${ }^{7}$

and Lee Law Review, forthcoming; H. Genn et al., Twisting Arms: Court Referred and Court Linked Mediation Under Judicial Pressure (Ministry of Justice Research Series, 2007); L. Blomgren Amsler (formerly Bingham), J.K. Martinez, S.E. Smith and C. Merchant, 'The State of Dispute System Design' (2015) 33 Conflict Resolution Quarterly S7; A. Kupfer Schneider, 'Foreword: The Future of Court ADR: Mediation and Beyond' (2012) 95(3) Marquette Law Review (Spring); T. Sourdin and A. Zariski, The Multi-Tasking Judge: Introduction to Comparative Judicial Dispute Resolution (Sydney: Thomson Reuters, 2013); D. Quek Anderson and J. Lee, 'The Global Pound Conference: A Conversation on the Future of Dispute Resolution' (2016) Asian Journal on Mediation 70.

3 See F.E.A. Sander, 'Varieties of Dispute Processing' in A. Levin and R. Wheeler (eds), The Pound Conference: Perspectives on Justice in the Future (West Publishing, 1979) pp. 65-87.

4 Civil Justice Reform, Interim Report and Consultation Paper (2001) p. 3, para. 9 .

5 Citing D. Bok, 'A Flawed System of Law Practice and Training' (1983) 33(4) Journal of Legal Education 570; R. Kagan, Adversarial Legalism: The American Way of Law (Cambridge, MA: Harvard University Press, 2001).

6 See e.g., C.J. Alkon. 'The Modern Problem-Solving Court Movement: Taking Stock After 25 Years', paper presented at Association of American Law Schools (AALS) Annual Conference 2016; and R. Fisher and W. Ury, Getting to Yes: Negotiating an Agreement Without Giving In (2nd edn, New York: Random House Business Books, 1991) pp. 10-11.

7 D.R. Hensler, 'Our Courts, Ourselves: How the Alternative Dispute Resolution Movement is Re-Shaping Our Legal System' (2003-2004) 108 Pennsylvania State Law Review 165. 
including reduction of caseloads, ${ }^{8}$ private and public sector efficiency, ${ }^{9}$ as well as extrinsic factors including relational, ${ }^{10}$ societal ${ }^{11}$ and processbased $^{12}$ considerations. Examining the impact of such programmes is critical, since 'with little . . information about the process or outcomes of dispute resolution, citizens' abilities to use the justice system effectively to achieve social change' is limited. ${ }^{13}$

Significant variation in the implementation of court mediation reforms currently exists. In some jurisdictions, mediation is mandated for particular civil case types, whereas in others, parties are encouraged to engage in voluntary mediation with cost consequences being attached in some jurisdictions to unreasonable refusal to engage in mediation. At the individual level, such programmes reflect distinct applications of individual rights suggesting self-determination and party choice in regulatory practice. ${ }^{14}$ On the other hand, notions of collective responsibility place importance on reducing the costs of litigation on society as a whole. Avenues toward voluntary or mandatory mediation reflect varying underlying normative conceptions of individual and collective justice. Given that 'public means available for financing dispute resolution are not unlimited', ${ }^{15}$ a balancing of individual process choices and social efficiency requires careful investigation.

In responding to calls for expanded empirical research exploring the operation ${ }^{16}$ and implementation ${ }^{17}$ of civil justice reforms, and building on

8 H. Foo Chee, Civil Case Management in Singapore: Of Models, Measures and Justice (ASEAN Law Association, 2016), available at www.aseanlawassociation. org/11GAdocs/workshop2-sg.pdf (accessed 14 January 2016).

9 W. Maclons, Mandatory Court Based Mediation as an Alternative Dispute Resolution Process in the South African Civil Justice System (University of Western Cape, 2014) p. 85.

${ }_{10}$ Y. Shamir, Alternative Dispute Resolution Approaches and Their Application (UNESCO, 2003) p. 24.

11 Mediate.com, Engineering Peace: Achieving the Promise of Mediation in the

World's Most Difficult Conflicts, available at www.mediate.com/articles/engpeace. cfm\#_edn7 (accessed 19 January 2016).

12 R. Zeinemann, 'The Characterisation of Public Sector Mediator' (2003)

24(2) Environs Law 51, available at http://environs.law.ucdavis.edu/volumes/24/2/ articles/zeinemann.pdf.

13 Hensler, 'Our Courts Ourselves' (n. 7 above).

14 Steffek et al., Regulating Dispute Resolution (n. 2 above).

15 Ibid.

16 See M. Heise, 'Justice Delayed? An Empirical Analysis of Civil Case Disposition Time' (2000) 50(4) Case Western Reserve Law Review 813; C. Tobias, 'Civil Justice Delay and Empirical Data: A Response to Professor Heise' (2000) 51(2) Case Western Reserve Law Review 235.

17 See T. Stipanowich, 'The International Evolution of Mediation: A Call for Dialogue and Deliberation' (2015) 46 Victoria University of Wellington 
an important foundation of rich scholarship examining the extension ${ }^{18}$ and usage ${ }^{19}$ of court mandated mediation; experience of procedural justice; ${ }^{20}$ investigation of efficiency claims; ${ }^{21}$ impacts on the quality and means ${ }^{22}$ of access; ${ }^{23}$ social justice and minority impacts; ${ }^{24}$ settlement outcomes; ${ }^{25}$ and cultural factors, ${ }^{26}$ this book presents a set of 10 longitudinal country case studies supplemented by survey research about the per-

Law Review 1191; Pepperdine University Legal Studies Research Paper No. 2016/1.

18 C. Menkel-Meadow, 'Pursuing Settlement in an Adversary Culture: A Tale of Innovation Co-opted or the Law of ADR' (1991) 19 Florida State Law Review 1; J. Resnik, 'Many Doors? Closing Doors? Alternative Dispute Resolution and Adjudication' (1995) 10 Ohio State Journal of Dispute Resolution 211; E.E. Deason, 'Procedural Rules for Complementary Systems of Litigation and Mediation: Worldwide' (2004) 80 Notre Dame Law Review 553.

19 See T.C.W. Farrow, Civil Justice, Privatization and Democracy (2011), available at http://papers.ssrn.com.eproxy1.lib.hku.hk/sol3/papers.cfm?abstract_id517 95407 (accessed 28 November 2011).

20 J. Thibaut and L. Walker, 'A Theory of Procedure' (1978) 66(3) California Law Review 541; D. Stienstra, M. Johnson, P. Lombard and M. Pecherski, Report to the Judicial Conference Committee on Court Administration and Case Management: A Study of Five Demonstration Programs Established Under the Civil Justice Reform Act of 1990 (Washington, DC: Federal Judicial Center, 1997).

21 D.R. Hensler, A Research Agenda: What We Need to Know About CourtConnected ADR (Santa Monica, CA: RAND Corporation, 2000), available at www.rand.org/pubs/reprints/RP871.html; T.J. Stipanowich, 'ADR and the 'Vanishing Trial': The Growth and Impact of Alternative Dispute Resolution' (2004) 1(3) Journal of Empirical Legal Studies 843; K. Kressel and D.G. Pruitt, 'Themes in the Mediation of Social Conflict' (1985) 41 Journal of Social Issues 179; J. Kakalik et al., Just, Speedy and Inexpensive? An Evaluation of Judicial Case Management Under the Civil Justice Reform Act (Santa Monica, CA: RAND, 1997).

22 See H. Genn, Paths to Justice (Oxford: Hart, 1999); Genn, 'Judging Civil Justice' (n. 1 above).

23 H. Genn, 'What is Civil Justice For? Reform, ADR, and Access to Justice' (2013) 24 Yale Journal of Law and the Humanities 397.

24 R. Delgado et al., 'Fairness and Formality: Minimizing the Risk of Prejudice in Alternative Dispute Resolution' (1985) Wisconsin Law Review 1359; G. LaFree and C. Rack, 'The Effects of Participants' Ethnicity and Gender on Monetary Outcomes in Mediated and Adjudicated Civil Cases' (1996) 30 Law and Society Review 767; S. Press, 'Court-Connected Mediation and Minorities: Has Any Progress Been Made?' (2013) ABA Dispute Resolution Magazine 36 (Summer).

25 J.M. Brett, Z.I. Barsness and S.B. Goldberg, 'The Effectiveness of Mediation: An Independent Analysis of Cases Handled by Four Major Service Providers' (1996) 12(3) Negotiation Journal 259; M. Galanter and M. Cahill, 'Most Cases Settle: Judicial Promotion and Regulation of Settlements' (1994) 46 Stanford Law Review 1339.

26 See Heise, 'Justice Delayed?' (n. 16 above). 
ceptions, observations and experiences of court mediation practitioners from diverse regions in order to gain insight into the dynamics, strengths and challenges of mandatory and voluntary court mediation programmes. It aims to respond to calls for 'empirical studies of the effectiveness of ADR' especially outside of North America, including comparative studies within and between mediation programme types, including mandatory and voluntary programmes. ${ }^{27}$ In particular, this book contributes to a growing body of empirical scholarship on the experience of civil justice in countries that have implemented mediation reforms, including the United Kingdom, Hong Kong, France, the Netherlands, Malaysia, the United States, Australia, Italy, China and India.

The degree of movement along the voluntary or mandatory mediation spectrum varies from one jurisdiction to another. Such variation exists with respect to the 'initiation control' 28 of mediation ${ }^{29}$ where approaches range from mandatory assignments for all cases under a particular monetary amount or case type, compelled orders to mediation

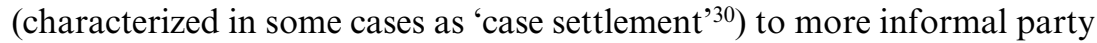
directed initiation of mediation. ${ }^{31}$ As described by Menkel-Meadow, the intermediaries facilitating judicial mediation sessions vary from judges provided by the courts, to private mediators. ${ }^{32}$ In addition, parties' duties concerning engagement in mediation may also differ. Some states use 'opt-out' rules where parties to a particular case type are automatically subjected to mediation unless there is a good reason for opting out, ${ }^{33}$ while other programmes use an 'opt-in' mechanism by which adverse cost consequences are imposed if parties unreasonably refuse to participate

27 L. Bingham et al., 'Dispute Resolution and the Vanishing Trial: Comparing Federal Government Litigation and ADR Outcomes' (2009) 24(2) Ohio State Journal of Dispute Resolution 1.

28 Steffek et al., Regulating Dispute Resolution (n. 2 above).

29 C. Menkel-Meadow, 'Variations in the Uptake of and Resistance to Mediation Outside of the United States' in A. Rovine (ed.), Contemporary Issues in International Arbitration and Mediation: The Fordham Papers 2014 (Leiden: Brill-Nijhoff, 2015) p. 197.

30 M. Mironi, 'Mediation v. Case Settlement: The Unsettling Relations Between Court and Mediation, A Case Study' (2014) 19 Harvard Negotiation Law Review 173; the distinction outlined by Mironi between 'mediation' and 'case settlement' is helpful, noting that mediation is characterized by an interest-based, party focused process rather than a 'settlement' oriented rights-based positional discourse.

31 Menkel-Meadow, 'Variations in the Uptake of and Resistance to Mediation' (n. 29 above) p. 197.

32 Ibid.

33 Ibid. 
in mediation or behave unreasonably. As has been well documented by Stipanowich's extensive meta-survey of court connected mediation in the United States, even within a common court mandated mediation programme, differential levels of judge-directed encouragement may lead to widely differing user experiences of the process. ${ }^{34}$ Existing empirical work examining mandatory and voluntary programme outcomes has found that selection and uptake of diverse programme structures is largely dependent on domestic factors, including the level of cooperation by the Bar, ${ }^{35}$ mediation awareness, socio-cultural context and harmonizing legislation. ${ }^{36}$ At the global level, soft-law-making bodies such as UNCITRAL have generally left open the question of mediation programme design to be inclusive of both voluntary and mandatory modalities depending on domestic circumstances. ${ }^{37}$

For purposes of this project, voluntary mediation jurisdictions are characterized as those requiring formal party-agreement prior to commencement, ${ }^{38}$ while mandatory mediation jurisdictions are classified, following Sander's definition, as consisting of both 'categorical' ${ }^{39}$ automatic referral programmes for certain categories of cases $^{40}$ and 'discretionary' such that judges have authority to order mediation where there is no consent from the parties. In jurisdictions where mixed methods of voluntary and mandatory resolution options co-exist, reference is made to the primary mechanism employed in non-family civil trials. In cases of varying federal and state programmes, reference is made to federal programme features. Despite efforts to achieve accurate groupings, limitations exist in such broad characterizations and future studies will no doubt further refine such categorizations and improve upon them.

34 T.J. Stipanowich, 'ADR and the 'Vanishing Trial': The Growth and Impact of Alternative Dispute Resolution' (2004) 1(3) Journal of Empirical Legal Studies 843.

35 See generally, P. Taivalkoski and A. Pynnä, 'The Courts and Bar Association as Drivers for Mediation in Finland' in New Developments in Civil and Commercial Mediation (New York: Springer, 2015) pp. 275-89.

36 Ibid.

37 United Nations (ed.), UNCITRAL Model Law on International Commercial Conciliation with Guide to Enactment and Use 2002 (New York: United Nations, 2002) p. 55, Art. 3.

${ }_{38}$ See H. Anderson and R. Pi, Evaluation of the Early Mediation Pilot Programs (Judicial Council of CA Administrative Office of the Courts, 2004).

39 F.E.A. Sander, 'Another View of Mandatory Mediation' (2007) 13(2) Dispute Resolution Magazine 16.

40 M. Hanks, 'Perspective on Mandatory Mediation' (2012) 35(3) University of New South Wales Law Journal 929. 


\section{DATA COLLECTION METHODS}

Contemporary scholars have acknowledged the challenges of obtaining sound empirical data on diverse ADR mechanisms, especially on courtannexed mediation. ${ }^{41}$ On the one hand, aggregated data from surveys and interviews provide the basis for comparisons yet may lack interpretive consistency. ${ }^{42}$ On the other hand, qualitative, in-depth analysis of a particular mediation event ${ }^{43}$ may afford rich insights, yet may not be representative. Useful insights have been drawn from studies disaggregating perceptions of attorneys, clients and mediators within the same mediation process and across regions of practice. ${ }^{44}$ Given such challenges, scholars have suggested that, to the extent possible, suitable quantitative and qualitative metrics should be examined in combination. ${ }^{45}$

In response to such observations, the research methodology employed here triangulates the exploration of judicial mediation reform by drawing on a combination of 10 voluntary and mandatory mediation country case studies coupled with longitudinal analysis of changes to judicial efficiency,

41 C. Menkel-Meadow, 'The Baseline Problem of What ADR is and What It is Compared To' in P. Cane and H. Kritzer (eds), Oxford Handbook of Empirical Legal Research (Oxford University Press, 2010); T.J. Stipanowich, 'ADR and the "Vanishing Trial": The Growth and Impact of Alternative Dispute Resolution' (2004) 1(3) Journal of Empirical Legal Studies 843; C. Menkel-Meadow et al., 'Thinking Critically about Nonadjudicatory Processes' in Dispute Resolution: Beyond the Adversarial Model (Aspen, 2005) pp. 875-6; M. Galanter et al., 'How to Improve Civil Justice Policy' (1994) 77 Judicature 185; D.R. Hensler, Why We Don't Know More About the Civil Justice System - and What We Could Do About It (USC Law, 1994); B. McAdoo, 'All Rise, the Court is in Session: What Judges Say About Court-Connected Mediation' (2006) 22(2) Ohio State Journal on Dispute Resolution 337.

42 Menkel-Meadow et al., 'Thinking Critically about Nonadjudicatory Processes' (n. 41 above).

43 Ibid.

44 See: T.J. Stipanowich, 'Beyond Arbitration: Innovation and Evolution in the United States Construction Industry' 31 Wake Forest L. Rev. 169 (1996); T.J. Stipanowich, "ADR and the "Vanishing Trial": The Growth and Impact of Alternative Dispute Resolution' (2004) 1(3) Journal of Empirical Legal Studies 843; T.J. Stipanowich, 'Insights on Mediator Practices and Perceptions' (2016) Disp. Resol. Mag., Winter 2016, at 4.

45 Ibid.; see also D.R. Hensler and M.A. Gasperetti, 'The Role of Empirical Legal Studies in Legal Scholarship, Legal Education and Policy-Making: A U.S. Perspective' in R. van Gestel, H.-W. Micklitz and E.L. Rubin (eds), Rethinking Legal Scholarship: A Transatlantic Dialogue (New York: Cambridge University Press, 2017); see also T. Ginsburg, P.G. Monateri and F. Parisi, Classics in Comparative Law: An Introduction (Cheltenham: Edward Elgar, 2014). 
perceptions of justice and overall confidence in the court system over a five-year time period since the implementation of such programmes. It supplements such findings with comparative examination of global court user experience data, ${ }^{46}$ and analysis of survey data from 83 practitioners, including judges, attorneys, administrators, mediators and participants practising in the area of court mediation reform. The aim is that through a process of triangulation the selected research techniques can, to some extent, compensate for inherent deficiencies in any one method alone, and provide a broader foundation for critical analysis ${ }^{47}$ Country case studies are selected from a non-random sample of 10 countries consisting of five regions in a 'mandatory mediation regions' group and five in a 'voluntary mediation regions' tracking intra-regional changes, if any, to levels of efficiency, confidence and perceptions of justice following the implementation of court mediation reforms over a five-year time-frame. ${ }^{48}$ Within each group of five, at least two common law and two civil law jurisdictions are selected, with at least two in each group being from an economically

46 Judicial and governance indicators are selected from survey databases including the World Bank Group's Worldwide Governance Indicators (WGI) (World Bank Group, 2016), available at http://info.worldbank.org/governance/ wgi/index.aspx\#home; the World Economic Forum's Global Competitiveness Report (GCR) and the World Justice Project's Rule of Law Index (ROI). This data was analysed by country and coded according to judicial mediation approach. The WGI is based on more than 30 individual data sources produced by various survey institutes, think tanks, non-governmental organizations, international organizations and private sector firms. Indicators in GCR are derived from the International Monetary Fund, the World Economic Forum and the Executive Opinion Survey. Indicators in the ROI are derived from a general public polling (GPP) and qualified respondent questionnaires (QRQs) (see World Justice Project, Rule of Law Index 2016).

47 D.T. Campbell and D.W. Fiske, 'Convergent and Discriminant Validation by the Multitrait-Multimethod Matrix' (1959) Psychology Bulletin 56, 81; N.K. Denzin, The Research Act: A Theoretical Introduction to Sociological Methods (New York: McGraw-Hill, 1978); J.A. Cook and M.M. Fonow, Beyond Methodology: Feminist Scholarship as Lived Research (Bloomington, IN: Indiana University Press, 1991).

48 On small-n sampling methodology, see J. Gerring, Case Study Research: Principles and Practices (Cambridge University Press, 2007); R. Hirschl, 'The Question of Case Selection in Comparative Constitutional Law' (2005) American Journal of Comparative Law 53. For countries in which divergent court mediation programmes exist at the federal and state level, categorization is made with reference to court practice at the federal level. This research background is also discussed in S. Ali, Nudging Civil Justice: Examining Voluntary and Mandatory Court Mediation Experience in Diverse Regions, forthcoming. 
advanced (OECD) country. Within the civil law groupings, both primary and secondary civil law jurisdictions are selected.

With respect to measures of efficiency, confidence and perceptions of justice, civil justice indicators and court opinion data are selected from survey databases including the World Bank Group's Worldwide Governance Indicators (WGI) ${ }^{49}$, the World Economic Forum's Global Competitiveness Report (GCR) $)^{50}$ and the World Justice Project's Rule of Law Index (ROI). ${ }^{51}$ In particular, efficiency is measured through an aggregation of indicators measuring operational cost in civil justice, accessibility and affordability and lack of delay in resolution. ${ }^{52}$ Confidence is examined in relation to the overall ranking of the civil justice system, ease of enforcement and impartial and effective ADR ${ }^{53}$ Finally, perceptions of justice are assessed through measures of rule of law and levels

49 See n. 46 above.

50 See 'Technical Notes and Sources' in Global Competitiveness Report 20142015 pp. 537-45 for a detailed description of sources for individual indicators. Indicators in the GCR are derived from the International Monetary Fund, the World Economic Forum and the Executive Opinion Survey.

51 World Justice Project, Rule of Law Index 2015 p. 15. It is conducted by leading local polling companies using a representative sample of 1,000 respondents in the three largest cities of each country. Indicators in the ROI are derived from a general public polling (GPP) and qualified respondent questionnaires (QRQs).

52 For purposes of the study, efficiency is measured through an aggregation of the following indicators: Efficiency of Legal Framework in Settling Disputes: this indicator appears in the Global Competitiveness Report. It measures the efficiency of the legal framework in settling disputes. Data was collected from the Executive Opinion Survey where participants rate the efficiency of the legal framework in their countries on a 1 to 7 scale. Data from the World Economic Forum was also used in generating the results. Accessibility and Affordability: this indicator appears in the World Justice Project Rule of Law Index. It indicates people's awareness of available remedies and the accessibility and affordability of courts, legal advice and representation. It also examines the extent to which court procedures and costs affect the accessibility and affordability of civil justice. No Unreasonable Delay: this indicator appears in the World Justice Project Rule of Law Index. It indicates the level of delay in adjudicating disputes and general perception of delay.

${ }_{53}$ For purposes of the study, confidence is measured through an aggregation of: Overall Civil Justice Ranking: this ranking is included in the World Justice Project's Rule of Law Index and measures the overall ranking of civil justice systems. Impartial and Effective ADR: this indicator appears in the World Justice Project Rule of Law Index. It measures the accessibility, impartiality, efficiency and the effectiveness in enforcing decisions reached through mediation. It also examines whether mediation is free of improper influence. Effective Enforcement: this indicator appears in the World Justice Project Rule of Law Index. It indicates levels of effectiveness in enforcing judgments and the delays in enforcing decisions. 
of reported discrimination. ${ }^{54}$ Indicator analysis, while providing useful insights, reflects inherent limitations, including challenges associated with the existence of intervening and exogenous variables, and therefore is supplemented by contextual case investigation of civil justice dynamics and survey data.

To provide comparative analysis, case studies and longitudinal data are supplemented by survey data collected from 83 mediation practitioners working in five regions. The survey was conducted between September 2015 and January 2017. A total of 120 surveys were distributed in person and initiated via a weblink portal and 83 surveys were completed. The aim of the survey was to gain insight into the dynamics, challenges and lessons learned in the context of mandatory and voluntary court mediation programmes and the impact of programme type, if any, on perceptions of confidence, fairness and efficiency. Given the small sample size $(n=83)$ the survey data cannot be considered generalizable.

The aim is that the multiple research methods employed here, while limited, together can contribute insights to an evolving understanding of the efficacy of diverse civil mediation policy approaches from the perspective of those directly engaged in the work of civil justice administration.

\section{LIMITATIONS}

The question of voluntary or mandatory programme design is highly context dependent. As noted in an earlier study of mandatory and voluntary

54 Perceptions of Justice are examined through the following indicators: Level of Discrimination: this indicator appears in the World Justice Project Rule of Law Index. It indicates the extent to which a person's economic and social status, e.g. sex, race, religion, place of origin or sexual orientation, affect one's access to civil justice. Rule of Law: the Worldwide Governance Indicators defines rule of law as the 'perceptions of the extent to which agents have confidence in and abide by the rules of society, and in particular the quality of contract enforcement, property rights, the police, and the courts, as well as the likelihood of crime and violence'. With respect to rule of law, legal scholars have argued that the rule of law can co-exist beyond the formal boundaries of courts to include more informal procedures such as mediation and traditional conciliation methods. See e.g. R.C. Reuben, 'ADR and the Rule of Law: Making the Connection' (2010) 16(4) Dispute Resolution Magazine 4; R.C. Reuben, 'How ADR Can Foster the Rule of Law: Beyond the Fundamental Tension', paper presented at Symposium on ADR and the Rule of Law: Making the Connection, Missouri School of Law, 15 October 2010; and M. Krygier, 'Legal Pluralism and the Value of the Rule of Law', paper presented at HKU-UNSW Research Symposium, Sydney, Australia, 4-5 December 2015. 
programmes, 'the differences in the structure and court environments ... mean that each program ... is unique: they cannot simply be lumped together and viewed generically'. ${ }^{55}$ While the study reports on the programme's correlation with the same measures including efficiency, confidence and perceptions of justice, the results must be seen as reflecting the unique conditions of each particular programme and 'any crossprogram comparisons must therefore take into account the impact of ... environmental differences on these results'. ${ }^{56}$ In addition, given the small sample size of the country case studies $(n=10)$ and survey research $(n=83)$, lack of policy uniformity in some cases, and the fact that in some regions, elements of voluntary and mandatory systems may co-exist, the results cannot be considered generalizable but rather aim at offering initial insights into the dynamics of diverse civil mediation policy approaches in the selected regions. The aim is that future studies will continue to refine and develop increasingly more accurate approaches to the analysis of such relationships. Insights from practice will no doubt assist in outlining directions for further study with the wider objective of developing a court system responsive to user needs. This being the case, several key insights may be drawn from the study as follows.

\section{SUMMARY OF FINDINGS}

The principal findings of the 10 country case studies, survey research and analysis of civil justice indicators indicate that overall, while both voluntary and mandatory mediation programmes demonstrate unique programmatic strengths and are associated with positive gains in the advancement of civil justice quality over a five-year period since implementation, sampled voluntary mediation programme regions are associated with a slightly higher proportion of longitudinal advancement in levels of efficiency, and perceptions of justice with a nearly equal proportion of advancement in levels of confidence, and an identical proportion of voluntary and mandatory regions experiencing positive advancement in the sub-categories of impartial and effective ADR (see Figure I.1). Comparative t-test analysis of a non-generalizable small-n 12 country comparison of 2016 civil justice indicators similarly suggest that sampled countries implementing voluntary court mediation programmes on average are associated with

55 Anderson and Pi, Evaluation of the Early Mediation Pilot Programs (n. 38 above).

56 Ibid. 
statistically significantly higher jurisdictional scores for efficiency and non-discrimination with higher, though non-significant difference with respect to the quality of civil justice, effective enforcement, accessibility and affordability and impartiality and effectiveness between voluntary and mandatory mediation systems. ${ }^{57}$ To some extent, such findings correspond with insights from 'nudge theory' suggesting that positive reinforcement is at least as effective as directions issued through court rules. ${ }^{58}$ At the same time, encouragement of mediation coupled with high quality mediators and supportive infrastructure can, in appropriate contexts, assist individuals, the wider community and judiciaries to achieve high quality outcomes.

While such statistical findings may be informative in a limited sense, correlation of changes in civil justice systems and perceptions of efficiency, justice and confidence over time or even in the aggregate are not a sign of a causal relationship. At the same time, it is clear that civil justice quality indicators in many cases mutually influence one another. For example, the quality of a given civil justice system may make it prone to select one form of court mediation over another. A diversity of external, exogenous and intervening variables including court financing, cultural factors and wider socio-political environment also impact programme outcomes and mediation programme design. Moreover, given the non-random, small-n sample, such findings cannot be considered generalizable. The aim is

57 For complete discussion, see S. Ali, Nudging Civil Justice: Examining Voluntary and Mandatory Court Mediation Experience in Diverse Regions, forthcoming. Given the non-random, small $\mathrm{n}$ sample, as well as the influence of highly variable socio-economic contexts of the sampled countries, such findings cannot be considered generalizable.

Average Civil Justice Indicator Scores by Voluntary and Mandatory Mediation Program Type

Percentile scores (out of 100)

Vol. Std. dev. Mand. Std. dev.

Accessibility and affordability*

Impartiality/effectiveness

No discrimination* average average

Effective enforcement*

62.40

79

71.8

0.62

48.8

12.25

Ranking

Efficiency* [138 countries]

Quality of civil justice* [113

74.4

15.36

70.8

13.29

51.2

10.15

11.7

57.2

17.9

countries]

12.2

20.2

8.4

52.4

47.6

* Indicates statistically significant difference.

58 Ibid. 
that the examination of such relationships, rather than provide for generalizable findings, can provide insights suggesting directions for further analysis. Such relationships suggest, for example, that in environments of higher reported discrimination, safeguards including those aimed at addressing implicit bias ${ }^{59}$ and lax civil ${ }^{60}$ and procedural ${ }^{61}$ justice compliance will be necessary to safeguard the integrity of the mediation process. The findings also echo insights from socio-legal scholars of civil mediation reform that in some contexts, 'facilitation and encouragement together with selective and appropriate pressure are likely to be more effective and possibly more efficient than blanket coercion to mediate'. ${ }^{62}$ At the same time, the provision of high quality mediation coupled with contextual understanding will have a positive impact in increasingly complex forms of mediation. ${ }^{63}$

With respect to the analysis of 83 open-ended survey responses, the findings provide insights into the dynamics, challenges and lessons learned from the perspective of those directly engaged in the work of administering, representing and mediating civil claims. While slight variation exists such that practitioners report higher levels of confidence in mandatory mediation programmes ( 70 per cent) as opposed to voluntary programmes (64 per cent), and higher perceptions of efficiency with respect to voluntary programmes (77 per cent) as opposed to mandatory programmes (68 per cent), both regard voluntary ( 81 per cent) and mandatory ( 82 per cent) mediation programmes with relatively equal perceptions of fairness. It must be noted that varying judicial and cultural understandings of the concepts of 'confidence', 'efficiency' and 'fairness', may also influence results.

With respect to advancing programme quality, the survey findings provide insights into the dynamics, challenges and lessons learned from the perspective of those directly engaged in the work of administering,

59 C. Izumi, 'Implicit Bias and the Illusion of Mediator Neutrality' (2010) 34 Washington University Journal of Law and Policy 71.

60 See L. Edelman, 'Legal Ambiguity and Symbolic Structures: Organizational Mediation of Civil Rights Law' (1992) 97(6) American Journal of Sociology 1531; Feeley, The Process is the Punishment (n. 1 above); Albiston, 'The Rule of Law and the Litigation Process' (n. 1 above); Genn, Paths to Justice (n. 22 above); Genn, Judging Civil Justice (n. 1 above).

${ }_{61}$ Feeley, 'The Process is the Punishment' (n. 1 above); Albiston, 'The Rule of Law and the Litigation Process' (n. 1 above).

62 Genn et al., Twisting Arms (n. 2 above).

63 C. Menkel-Meadow, 'When Litigation is Not the Only Way: Consensus Building and Mediation as Public Interest Lawyering' (2002) 10 Washington University Journal of Law and Policy 37. 


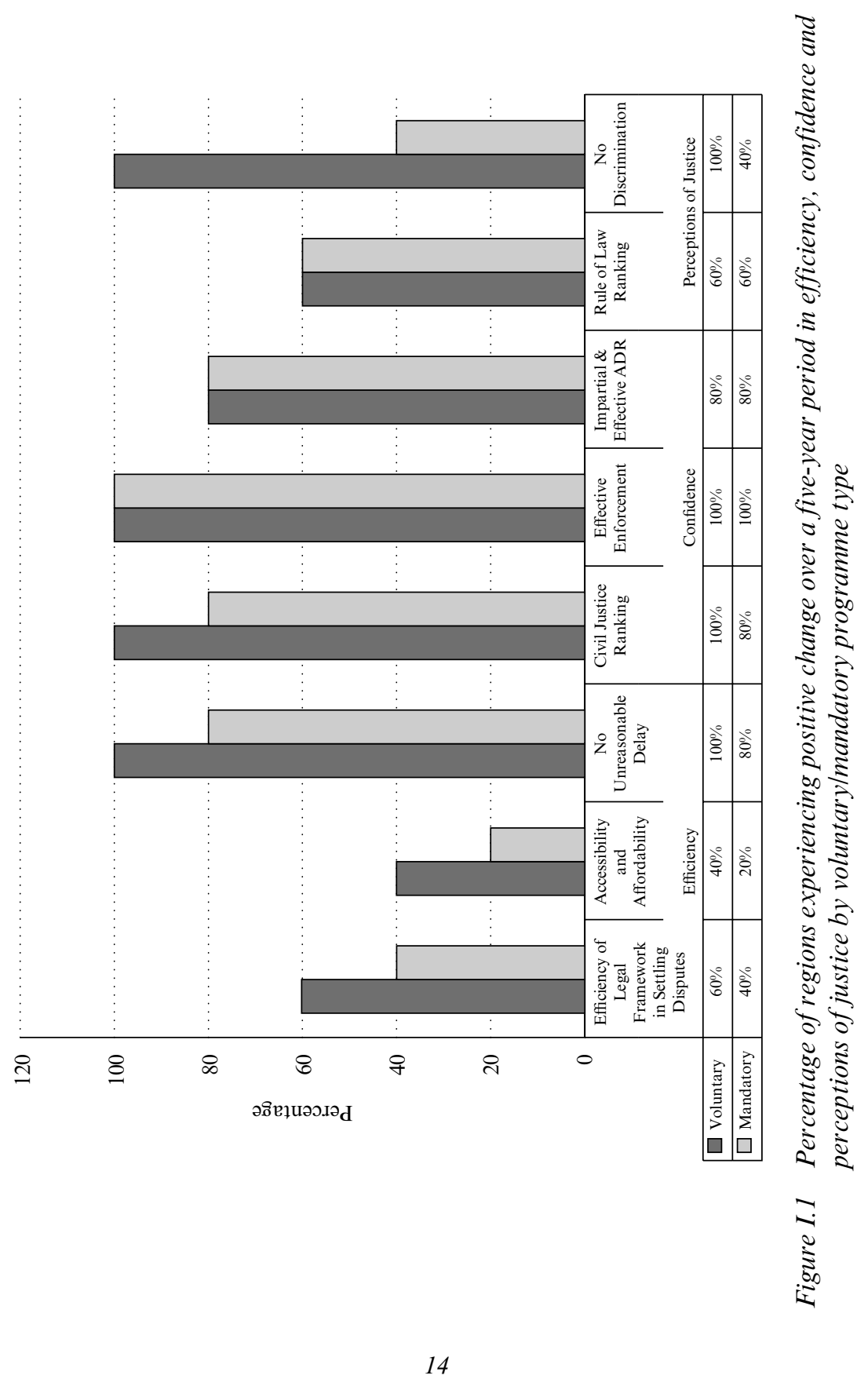


representing and mediating civil claims. In particular, the findings indicate that practitioners working in mandatory court mediation programmes identify several key benefits, including normalizing party-driven resolution, enhanced efficiency in some cases through effective case screening and contributing to relational repair, while practitioners working in voluntary programmes identified the key strengths of such programmes as the development of simple procedures and self-determined engagement. With respect to programme challenges, mandatory mediation practitioners noted that key challenges included limited party understanding of the mediation process, lawyer conflicts of interest, lack of good faith, and the need for greater experience in managing power imbalances. Both programme types highlighted resource limitations as a significant challenge, while challenges within voluntary court mediation programmes included difficulties associated with encouraging party participation and limited resources. Practitioner suggestions for improving the overall court mediation process ranged from enhanced training, public education, organizational resources, to ongoing evaluation and greater flexibility in settlement arrangements.

\section{THEORETICAL BACKGROUND}

Relevant to the question of mandatory and voluntary mediation programme design is the broader question of the process and place of mediation generally within the context of systems of civil justice. As judicial systems advance, evolving conceptions of justice are reflected in varying emphasis on the role, place and practice of mediation in civil courts. Exploring how such programmes can provide opportunities for party directed reconciliation, on the one hand, while at the same time ensure access to formal legal channels remains an area of continued inquiry. Beginning in the late 1970s, Lon Fuller and Owen Fiss articulated early insights into the role, forms and limits of adjudication. Fiss argued that the purpose of adjudication is to provide a public forum to enact public values and not a forum for settlement proceedings. ${ }^{64}$ Continuing this line of exploration, modern court mediation as a policy approach has not been without criticism. Chief among these arguments, similar to those raised by Fiss, is that such informal processes do not result in the development of public goods including rules of precedent, advocacy skills, publication of facts and enhanced authority of courts as

64 See O. Fiss, The Forms of Justice, Faculty Scholarship Series Paper 1220 (1979); O. Fiss, 'Against Settlement' (1984) 93(6) Yale Law Journal 1073. 
achieved through adjudication. ${ }^{65}$ Accordingly, this view holds that adjudication is a central part of political life because it contributes to the articulation of public values ${ }^{66}$ while at the same time acknowledging that only a small portion of disputes are occasions for structural transformation. ${ }^{67} \mathrm{Out}$ of court mediation has also been challenged ${ }^{68}$ based on the view that such processes enlarge social disputes, ${ }^{69}$ deformalize justice, diffuse legitimate indignation of parties ${ }^{70}$ are not suitable for high-conflict cases ${ }^{71}$ and pose an increased risk of outcomes coloured by prejudice. ${ }^{72}$ Similarly, scholars have suggested that in some cases, absent proper safeguards, women's interests may be undermined in the mediation process ${ }^{73}$ due to its absence of rules, and minimization of fault. ${ }^{74}$

In response to such criticisms, and consistent with Fuller's observations that alternative processes such as mediation are potentially appropriate in cases where adjudication has reached 'its limits' ${ }^{75}$ while contributing toward the creation of relevant interpersonal norms rather than the conformity to such norms ${ }^{76}$ particularly when parties concerned are locked in a relationship of 'heavy interdependence', such that each is dependent on some form of collaboration with the other, ${ }^{77}$ and the facilitation of a mediator can speed the discussion, reduce the likelihood of miscalculation and help parties reach an optimal agreement by adjusting the parties' divergent valuations, ${ }^{78}$ modern day scholars of mediation have put

65 D. Luban, 'Settlements and the Erosion of the Public Realm' (1995) 83 Georgetown Law Journal 2619.

66 Ibid.

67 Ibid.

68 R. Delgado, 'ADR and the Dispossessed: Recent Books about the Deformalization Movement' (1988) 13 Law and Social Inquiry 145.

69 Ibid.

70 Ibid.

71 O. Tjersland, W. Gulbrandsen and H. Haavind, 'Mandatory Mediation Outside the Court: A Process and Effect Study' (2015) 33 Conflict Resolution Quarterly 19.

72 Ibid.

73 T. Grillo, 'The Mediation Alternative: Process Dangers for Women' (1991) 100 Yale Law Journal 1545.

74 Ibid.

75 See L.L. Fuller, 'Forms and Limits of Adjudication' (1978) 92(2) Harvard Law Review 353; this occurred, Fuller argued, when adjudication attempted to resolve what he described as 'polycentric' type disputes (such as when there is no clear issue subject to proofs and contentions).

76 L.L. Fuller, 'Mediation: Its Forms and Functions' (1970) 44 Southern California Law Review 308.

77 Ibid. 310-12.

78 Ibid. 318. 
forward justifications for the continued support of 'process pluralism'79 through court-connected mediation on moral, policy and process-based grounds. In particular, scholars note ${ }^{80}$ that settlement can be justified on moral grounds consistent with fundamental values including participation, empowerment, dignity, respect, empathy, catharsis, privacy, efficiency, quality, equity, access and justice. ${ }^{81}$ Privacy may be useful in some cases, providing greater possibilities for just results, and deeper and richer access to justice ${ }^{82}$ and settlements absent consensus should not be enforced. ${ }^{83}$ Others have questioned whether justice can be achieved through the court system, ${ }^{84}$ and highlight the value of reconciliation of broken relationships through mediation. ${ }^{85}$ In addition, participant satisfaction ${ }^{86}$ and party selfdetermination ${ }^{87}$ have been cited as important contributions. ${ }^{88}$

In all cases, as recent research has found, innovations intended to reduce costs and delay should not do so at the expense of those qualities of the judicial process that are more important to litigants', ${ }^{89}$ most importantly the realization of justice. ${ }^{90}$ Institutions involved in the provision of court mediation services must be mindful of benchmarking success beyond measures of 'settlement' to actual resolution of issues through an impartial, just and principle-based process. ${ }^{91}$ The relative advantages of mediation in a given jurisdiction vary according to the functioning of the underlying national civil litigation system. Success largely depends on the

79 C. Menkel-Meadow, 'Peace and Justice: Notes on the Evolution and Purpose of Legal Process' (2006) 94 Georgetown Law Journal 553.

80 C. Menkel-Meadow, 'Whose Settlement is It Anyway? A Philosophical and Democratic Defense of Settlement (In Some Cases)' (1995) 83 Georgetown Law Journal 2663.

81 Ibid.

82 Ibid.

83 Ibid.

84 A.W. McThenia and T.L. Shaffer, 'For Reconciliation (1985) 94 Yale Law Journal 1660.

85 Ibid.

86 J. Thibaut and L. Walker, 'A Theory of Procedure' (1978) 66(3) California

Law Review 541; J.D. Rosenberg and H.J. Folberg, 'Alternative Dispute Resolution: An Empirical Analysis’ (1994) 46 Stanford Law Review 1487.

87 K.K. Kovach and L.P. Love, "Evaluative" Mediation is an Oxymoron' (1996) 14 Alternatives to High Cost Litigation (March).

88 Ibid.

89 E.A. Lind et al., The Perception of Justice: Tort Litigants' Views of Trial, Court-Annexed Arbitration, and Judicial Settlement Conferences (Santa Monica, CA: RAND, 1989).

90 Genn, Judging Civil Justice (n. 1 above).

91 See Genn, 'What is Civil Justice For?' (n. 23 above); Mironi, 'Mediation v. Case Settlement' (n. 30 above). 
quality and skill of the mediators, institutional support, party education and preparation, and engagement with local needs and conditions.

\section{OVERVIEW OF THE BOOK}

This book is divided into four parts, each of which analyses the dynamics of mandatory and voluntary court mediation programmes in selected regions and the relationship between programme type, if any, on perceptions of confidence, fairness and efficiency.

Part I examines the contribution of existing research examining the aims and objectives of court mediation reform. These include existing intrinsic and extrinsic rationales for the introduction of court mediation programmes, including efficiency, reduction of caseloads, private and public sector cost reductions, as well as relational, societal and process-based considerations. Chapter 2 builds on this analysis by examining, at a broad level, rationales for mandatory versus voluntary mediation programme design. Varying national experiences in relation to the global development of civil justice reforms in Asia Europe and North America ${ }^{92}$ seem to point mostly to the prominent influence of unique domestic factors in a country's eventual adoption of a particular mediation model, whether voluntary or mandatory. ${ }^{93}$

Following Part I, each of the voluntary and mandatory country case studies in Parts II and III systematically examines the policy background, programme features, practical implementation and achievements of court mediation programmes in 10 regions. In-depth case studies are supplemented by longitudinal research over a five-year time-frame, tracking changes (if any) to levels of efficiency, confidence and perceptions of

92 See N.M. Alexander, 'What's Law Got to Do with It? Mapping Modern Mediation Movements in Civil and Common Law Jurisdictions' (2001) 13(2) Bond Law Review Article 5; N.M. Alexander, International and Comparative Mediation: Legal Perspectives (The Hague: Kluwer Law International, 2009); B. Clark, Lawyers and Mediation (Berlin/Heidelberg: Springer, 2012); Genn, Judging Civil Justice (n. 1 above); M. Hanks, 'Perspectives on Mandatory Mediation' (2012) 35(3) University of New South Wales Law Journal 929; C. Menkel-Meadow and B. Garth, 'Process, People, Power and Policy: Empirical Studies of Civil Procedure and Courts' in P. Cane and H. Kritzer (eds), Oxford Handbook of Empirical Legal Research (Oxford University Press, 2010); J.M. Nolan-Haley, 'Mediation Exceptionality' (2010) 78 Fordham Law Review 1247.

93 See generally, E.E. Gordon, 'Why Attorneys Support Mandatory Mediation' (1998) 82 Judicature 224; Hanks, 'Perspectives on Mandatory Mediation' (n. 92 above) pp. 929-32. 
justice within each region following the implementation of court mediation reforms. Overall, both voluntary and mandatory programmes demonstrate positive movement in all indicator areas, with slightly higher levels of positive change in regions implementing voluntary court mediation programmes.

Part II explores the dynamics of voluntary mediation programmes in five jurisdictions including the United Kingdom, Hong Kong, France, the Netherlands and Malaysia. While a variety of factors impact civil justice programme outcomes, overall in the jurisdictions examined, over a five-year time period since the introduction of such reforms, 60 per cent of these jurisdictions have experienced positive internal movement in rankings relating to efficiency of settling disputes; 40 per cent have experienced positive development with respect to improved accessibility and affordability; 100 per cent have advanced in relation to reduction of delay; 100 per cent improved in relation to overall ranking in the quality of civil justice; 100 per cent advanced in relation to effective enforcement; 80 per cent experienced positive movement with respect to impartial and effective ADR; and 100 per cent experienced a reduction in the level of reported discrimination.

Part III examines mandatory mediation programmes in the United States, Australia, Italy, China and India. In general, key findings over a five-year time-frame similarly indicate positive developments in many areas. In particular, 40 per cent of these jurisdictions have experienced positive internal movement in rankings relating to efficiency of settling disputes; 20 per cent have experienced positive development with respect to improved accessibility and affordability; 80 per cent have advanced in relation to reduction of delay; 80 per cent improved in relation to the overall quality of civil justice; 100 per cent advanced in relation to effective enforcement; 80 per cent experienced positive movement with respect to impartial and effective ADR; and 40 per cent experienced a reduction in the level of reported discrimination.

Building on country case studies presented in Parts II and III exploring relative longitudinal gains in civil justice quality over a five-year period in mandatory and voluntary mediation countries, Part IV presents survey findings of 83 court mediation practitioners regarding their insights into the dynamics, challenges and lessons learned from the perspective of those directly engaged in the work of administering, representing and mediating civil claims. In particular, building on existing research findings, the survey examines insights into effective design of court mediation policy. It finds that key to improving court mediation programmes is overcoming a number of challenges, including the need for greater party understanding of the mediation process; overcoming conflicts of interest; 
enhancing mediator quality; developing greater capacity to manage power imbalances and overcome implicit and explicit biases and resource support through ongoing monitoring and evaluation. Such findings echo existing research suggesting that the formulation of mediation policy must respect party autonomy, ${ }^{94}$ comply with principles of justice and cost efficiency, ${ }^{95}$ and provide supportive infrastructure including financing, enforcement mechanisms and a reliable legal framework for mediation. ${ }^{96}$ Given the important role of economic and cultural factors ${ }^{97}$ in influencing the use of mediation in diverse regions,${ }^{98}$ including social, legal and historical factors, ${ }^{99}$ mandatory or voluntary policy must be sensitive to such variation. ${ }^{100}$

The question of voluntary or mandatory programme design is highly context dependent and as such the book does not purport to offer a unitary conclusion as to which type of programme is most effective in the abstract, but rather aims to reflect on the achievements of such programmes and what has led to success. In some contexts, systems that reinforce principles of autonomy, volition and choice in dispute resolution may result in more enriched experiences of confidence and perceptions of justice. In other contexts, particularly in cases involving relationships of heavy interdependence, absent abuse or harassment, parties may be best served by a more systematic consideration of mediation opportunities. Given the primary focus of this study on general civil claims, it must be noted that court referral of family cases to well-trained mediation staff resulting in well documented benefits to parties, is not the focus of the study and therefore beyond the scope of interpretation. As noted in an earlier study, 'the differences in the structure and court environments of ... programs mean that each program ... is unique: they cannot simply be lumped together and viewed generically'. ${ }^{101}$ While the study reports on the programmes' correlation with the same measures, including efficiency, confidence and perceptions of justice, the results must be seen as reflecting

\footnotetext{
94 Steffek et al., Regulating Dispute Resolution (n. 2 above) p. 15.

95 Ibid. 17.

96 Ibid. 18.

97 I. Macduff, 'Your Pace or Mine? Culture, Time and Negotiation' (2006) 22 Negotiation Journal 31.

98 Menkel-Meadow, 'Variations in the Uptake of and Resistance to Mediation' (n. 29 above).

99 Ibid. See also I. Macduff, 'The Role of Negotiation: Negotiated Justice?' (1995) 25 Victoria University Wellington Law Review 144.

100 Ibid.

101 Anderson and Pi, Evaluation of the Early Mediation Pilot Programs (n. 38
} above). 
the unique conditions of each particular programme and 'any crossprogram comparisons must therefore take into account the impact of programmatic and environmental differences on these results' ${ }^{102}$

On the whole, whether voluntary or mandatory, it can be suggested that at an early stage, small-scale pilot mediation programmes can provide a useful base of experience to develop culturally specific programmes and train a growing pool of capable mediators, engage in a collective process of learning and advance programme design. At the mid-stage as experience is gained, public information programmes can assist with the diffusion and expansion of such programmes in a given region. At an advanced stage, as high quality mediation services are developed and mediators receive adequate training in avoiding implicit bias, preventing the abuse of power imbalances, and institutional support and safeguards are in place to prevent discrimination and enhance access, then movement towards more targeted encouragement of mediation in appropriate cases can further enhance options for resolution. In all stages, ongoing learning through collaborative reflection on challenges and best practices will assist in the advancement of court mediation programmes and inform policy reform. Such ongoing learning, coupled with the provision of accessible public information on the mediation process, will contribute to enhanced efficacy. As recent research has found, 'innovations intended to reduce costs and delay should not do so at the expense of those qualities of the judicial process that are more important to litigants', including the realization of justice. ${ }^{103}$ Institutions involved in the provision of court mediation services must be mindful of benchmarking success beyond measures of 'settlement' to actual resolution of issues through an impartial, just and principle-based process. ${ }^{104}$ The relative advantages of mediation in a given jurisdiction will largely vary according to the quality and skill of the mediators, ${ }^{105}$ the underlying quality of the civil litigation system, institutional and financial support, ${ }^{106}$ party education and preparation, and engagement with local needs and conditions.

\footnotetext{
102 Ibid.

103 Lind et al., The Perception of Justice (n. 89 above).

104 See Genn, 'What is Civil Justice For?' (n. 23 above); Mironi, 'Mediation v. Case Settlement' (n. 20 above).

105 Empirical studies indicate that nearly 30 per cent of court mediators believe that further training is needed to effectively conduct mediations. See S. Purcell and J. Martinez, 'Mediators in the Field: Experiences Around the Globe' (2014) Dispute Resolution Magazine (Winter).

106 See J. McHale and T.C.W. Farrow, 'Mandatory Dispute Resolution and the Question of Resources' (2013) Slaw; J. McHale, 'Access to Justice: A Government Perspective' (2012) 63 University of New Brunswick Law Journal 352.
} 
Given the complexity of surrounding civil justice dynamics, much remains to be examined, including the need for more in-depth qualitative studies examining intra-mediation programme variation and how mediator and participant training including programmes directed toward the cultivation of relevant mediator capabilities including impartiality and equity interact with the development of surrounding mediation culture and the advancement of social justice, including the development of safeguards against bias and the promotion of enhanced cohesion. Future studies by a growing number of researchers will no doubt contribute insights to the advancement of such understanding. 